\title{
FAITH, INTOLERANCE, VIOLENCE AND BIGOTRY Legal and Constitutional Issues of Freedom of Religion in Indonesia ${ }^{1}$
}

\author{
Adam J. Fenton \\ London School of Public Relations, Jakarta - Indonesia | adam.jf@Ispr.edu
}

\begin{abstract}
Religious intolerance and bigotry indeed is a contributing factor in social and political conflict including manifestations of terrorist violence. While freedom of religion is enshrined in Indonesia's Constitution, social practices and governmental regulations fall short of constitutional and international law guarantees, allowing institutionalised bias in the treatment of religious minorities. Such bias inhibits Indonesia's transition to a fully-functioning pluralistic democracy and sacrifices democratic ideals of personal liberty and freedom of expression for the stated goals of religious and social harmony. The Ahok case precisely confirms that. The paper examines the constitutional bases of freedom of religion, Indonesia's Blasphemy Law and takes account of the history and tenets of Pancasila which dictate a belief in God as the first principle of state ideology. The paper argues that the Indonesian state's failure to recognise the legitimacy of alternate theological positions is a major obstacle to Indonesia recognising the ultimate ideal, enshrined in the national motto, of unity in diversity.
\end{abstract}

Keywords: freedom of religion, violence, intolerance, constitution.

\section{Introduction}

This field of inquiry is where philosophy, religion, politics, terrorism-even scientific method-all converge in the arena of current

\footnotetext{
${ }^{1}$ Based on a paper presented at the International Indonesia Forum IX, 23-24 August 2016 Atma Jaya Catholic University, Jakarta.
} 
world events. It is an area of utmost importance, as it deals with what is arguably the greatest challenge facing humanity; the pursuit of peaceful coexistence with other members of our species. Our collective failure to resolve this challenge may ultimately result in an increasingly catastrophic descent into global conflict.

This paper takes a multi-disciplinary approach to analysing issues relating to freedom of religion and intolerance as contributors to social conflict and terrorist violence. The paper combines philosophical, historical, communications theory, legal and political elements in the discussion, which focuses, primarily, on the situation as it currently exists in Indonesia. While much of the discussion centres on Indonesia, the ideas and arguments presented may apply more widely. The paper begins by citing various philosophical thinkers to argue for an "unaccustomed shift" in critical thinking; to challenge our own most fundamental beliefs. It argues that this approach can be used to support a meta-narrative of political secularism which may be a vital key to success in terrorism counter-ideology. The paper then examines and analyses a number of historical, constitutional and legal issues currently existing in Indonesia which influence and shape prevailing attitudes toward religious freedom and religious 'deviancy' or blasphemy. The paper concludes that a growing religious orthodoxy in Indonesia, supported by legislative frameworks, reacts strongly against ideologies which are considered to be outside the mainstream, severely inhibiting the religious or general freedom of thought required to challenge received 'wisdom' and to encourage innovation of ideas.

\section{Why Indonesia?}

It may reasonably be asked what relevance the Indonesian situation has to the rest of the world, and why Indonesia is worthy of attention in discussions on the topic of religious intolerance and terrorist violence. Indonesia has not only experienced its share of jihadist terrorism, ${ }^{2}$ its state responses to terrorism have reaped considerable results. ${ }^{3}$ It is often stated that Indonesia, can serve as a model of

2 For in-depth analysis of Indonesian terrorism issues see: www.understandingconflict.org.

3 Hannah Beech, 'What Indonesia Can Teach the World About Counterterrorism' (2010) TIME <http://www.time.com/time/magazine/article/0,9171,1992246,00.html\#ixzz1THb0itBv>. 
'moderate' Islam for the rest of the Muslim world. ${ }^{4}$ In February 2016, US President Barack Obama stated that his administration wanted to "partner" with Indonesia because it represents "the best of moderate Islam...their voice is absolutely critical in us winning the larger ideological battle that ISIS has mounted." 5

Governments, academics, religious leaders, even radical terrorist groups, all agree on one thing: ideology is important. ${ }^{6}$ Countering the radical ideology of terrorist groups, is a crucial step in defeating them; it is a war of words and ideology, and one of the main battlefields is in online forums-the 'town halls of the digital age'. 7 The counterideology recommended in this paper is one which recognises a global humanity and humanism, which challenges any form of accepted traditional 'knowledge' including religion, and challenges limitations on freedom of thought-whether those limitations are imposed by governments or by religion. The paper argues that the most effective response to Islamist extremism, is to depoliticise Islam through a "metanarrative of political secularism" 8 -that is, a counter-ideology ${ }^{4}$ Kamaruddin Amin, 'Can Indonesian Islam be a Model for the Rest of the Muslim
World?' (2016) The Jakarta Post < http://www.thejakartapost.com/news/2016-
/05/20/can-indonesian-islam-be-a-model-for-the-rest-of-the-muslim-world.html>.

${ }^{5}$ Lin Xueling, 'Exclusive: We want to partner ASEAN countries that represent best of moderate Islam, says Obama' (2016) Channel News Asia <http://www.channelnewsasia.com/news/asiapacific/exclusive-we-want-to/2533520.html>

${ }^{6}$ Mark Sedgwick, 'Jihadist ideology, Western counter-ideology, and the ABC model' (2012) 5(3) Critical Studies on Terrorism 359; Jacob Silverman, 'That Propaganda Program Bill Clinton Praised Hillary for? It Was Considered a Failure.' (2016) Politico Magazine <http://www.politico.com/magazine/story/2016/07/bill-clinton-hillary-clintoncounter-messaging-radicalization-islamists-214112>

7 Deen Freelon et al, 'Town Halls of the Digital Age: Controversy and Ideology in Online Deliberation (and Beyond)' (2008) October 16-18, 2008(Paper ID: 238) Internet Research 9.0 IT University of Copenhagen

${ }^{8}$ Halim Rane, 'Narratives and Counter-narratives of Islamist Extremism' in Anne Aly et al (eds), Violent Extremism Online: New Persectives on Terrorism and the Internet (Routledge, 2016) Rane notes "Studies that profile dozens of Muslim terrorism suspects in Europe (Rabasa and Benard 2015) and Australia (Bergin et. al. 2015) show that while some commence a university or diploma or degree, many drop out and do not obtain post-secondary school qualifications. Moreover, it is noteworthy that none of the suspects listed possess a humanities or social science degree. Those with tertiary qualifications tend to be trained in information technology, business, finance, engineering and science... A humanities or social science education may allow young Muslims to better understand history, society, religion and international relations 
emphasising freedom of thought, political expression and scientific inquiry, social justice as well as the "values of democracy, rule of law, equality of opportunity, and freedom from persecution". ?

As the largest Muslim-majority country, the third largest democracy, and the fourth most populous country in the world, what happens in Indonesia matters. Indonesian attitudes and practices with regard to issues like religion, terrorism, and the implementation of Shariah law, can influence global thinking and direction on these important issues.

While some of the discussion in this paper, particularly with reference to Indonesia's Constitution and state philosophy therefore do not directly apply to other countries, some of the arguments do apply more broadly. A bigot who does not tolerate conflicting points of view, whether Christian, Muslim, atheist or any other ideology, displays the same intolerance whether they are in Indonesia, the US, or elsewhere. This paper does not advocate atheism, agnosticism, communism or any other 'ism'. It advocates freedom of political and religious expression to allow a rational conversation and debate about these topics to occur in public fora - and is opposed to the blanket prohibition, and in some cases criminalisation, of discussions of such topics.

\section{On Doubt}

Philosopher and ethicist Peter Singer made the case for a radical change to human attitudes and practices by pointing out the need to occasionally "re-think" our own fundamental beliefs - even those which are the most "natural and inevitable". In 1990, he wrote:

In recent years a number of oppressed groups have campaigned vigorously for equality. The classic instance is the Black Liberation movement, which demands an end to the prejudice and discrimination that has made blacks second-class citizens. The immediate appeal of the black liberation movement and its initial, if limited, success made it a model for other oppressed groups to follow. We became familiar with liberation movements for Spanish-Americans, gay people, and a variety of other minorities.

which may enable them to not only resist and reject Islamist ideology and narratives, but to develop counter-narratives and a Western Muslim identity for the benefit of their community."

${ }^{9}$ Sedgwick, above $\mathrm{n}$ 
When a majority group-women-began their campaign, some thought we had come to the end of the road. Discrimination on the basis of sex, it has been said, is the last universally accepted form of discrimination, practiced without secrecy or pretense even in those liberal circles that have long prided themselves on their freedom from prejudice against racial minorities.

One should always be wary of talking of "the last remaining form of discrimination." If we have learnt anything from the liberation movements, we should have learnt how difficult it is to be aware of latent prejudice in our attitudes to particular groups until this prejudice is forcefully pointed out.

A liberation movement demands an expansion of our moral horizons and an extension or reinterpretation of the basic moral principle of equality. Practices that were previously regarded as natural and inevitable come to be seen as the result of unjustifiable prejudice. Who can say with confidence that all his or her attitudes and practices are beyond criticism? If we wish to avoid being numbered among the oppressors, we must be prepared to re-think even our most fundamental attitudes. We need to consider them from the point of view of those most disadvantaged by our attitudes, and the practices that follow from these attitudes. If we can make this unaccustomed mental switch we may discover a pattern in our attitudes and practices that consistently operates so as to benefit one group-usually the one to which we ourselves belong-at the expense of another. ${ }^{10}$

The "latent prejudice" discussed in this paper, is not that of humans toward non-humans, as Singer argued, it is that of the religious toward the non-religious, or the religious-other. The "unaccustomed mental switch" which must be made, is for religious people, to consider that their most fundamental attitude of faith in a particular religion may "number them among the oppressors". As Singer also stated, "All this may sound a little far-fetched, more like a parody of other liberation movements than a serious objective."

To religious people, particularly those belonging to Indonesia's Muslim majority, it may seem like a joke, until we consider that in 2012, an Indonesian man, Alexander Aan, was sentenced to two and a half years imprisonment for stating on his Facebook page that he was

\footnotetext{
${ }^{10}$ Peter Singer, 'All Animals Are Equal ' in Tom Regan and Peter Singer (eds), Animal Rights and Human Obligations (Prentice Hall, Second ed, 1989), p. 148.
} 
an atheist. ${ }^{11}$ Acts of extreme violence against followers of the minority Ahmadiyah Islamic sect are well documented in Indonesia. ${ }^{12}$ Governmental practices of granting, withholding or cancelling, building permits for non-majority places of worship indicate serious insitutionalised bias in, particularly, Indonesia's provincial and local governments. ${ }^{13}$ Widespread anti-LGBT stances, largely driven by religious views, have led to institutionalised prejudice in political, religious and medical institutions-notably the promulgation of local bylaws which criminalise homosexuality and the categorisation of homosexuality as a mental illness. ${ }^{14}$ The last and still lingering case is Ahok blasphemy case. ${ }^{15}$

Makin points out that while Indonesia's "wonderful" diversity is often referred to when promoting Indonesia to the world as a travel destination, pluralism of religion has been consistently denied by

11 Joe Cochrane, 'Embrace of Atheism Put an Indonesian in Prison' (2014) New York Times <http://www.nytimes.com/2014/05/04/world/asia/indonesian-who-embraced-atheism-landed-in-prison.html>

${ }^{12}$ Niniek Karmini, 'No Shame for Religious Killings in Indonesian Town', The Jakarta Globe August 09, 20112011 < http://www.thejakartaglobe.com/home/no-shame-forreligious-killings-in-indonesian-town/458163>

${ }^{13}$ Melissa Crouch, 'Implementing the Regulation on Places of Worship in Indonesia: New Problems, Local Politics and Court Action' (2010) 34 Asian Studies Review 403.

14 Jamison Liang and IA, 'Morality and LGBT rights in Indonesia ' (2016) New Mandala <http://www.newmandala.org/morality-and-lgbt-rights-in-indonesia/>

15 The case began with a viral video showing Ahok (Basuki Cahaya Purnama) the governor of Jakarta who happens to be a Chinese descent and non-Muslim complaining the use of Qur'anic verse (5:51) by certain conservative Muslim clerics to urge Muslim community in Jakarta for not to vote him the 2017 upcoming governor election. The governor speech was on 27 of September 2016 then he was reported to police by Habib Novel Hasan on 6 of November 2016, a conservative Muslim cleric of Front of Islam's Defender (Front Pembela Islam; FPI). Huge Muslim masses rallied in Jakarta on 4 of November demanding Ahok prosecution for blasphemy and on 16 of November 2016 the police named Ahok as suspect. Another conservative mass rally took place in Jakarta on 2 of December 2016 to further reinforce conservative stance. See for instance: Timeline of Ahok Case, Pressreader, https://www.pressreader.com/indonesia/the-jakarta-post/20161107/281547995456899 and Indonesia: Drop blasphemy case against Jakarta Governor, Amnesty International, https://www.amnesty.org/en/latest/news/2016/11/indonesia-drop-case-against-jakarta-governor/ 
successive governments since Soekarno. ${ }^{16} \mathrm{He}$ notes the irony that "imported" religions such as Islam, Buddhism and Christianity are acknowledged by the government, whereas the existence of indigenous religions is denied; and leaders and followers of 'deviant' sects often face prosecution and imprisonment under the Blasphemy Law of 1965.17 In Makin's analysis, this is the result of "the growing pressure of Islamic orthodoxy which often shows its muscle to control political and social dimensions". 18

A religious reader may object at this point, and say "Yes, but just because I hold strong religious views does not mean that I, or any religious person, will commit acts of bigotry or violence!" This is, of course, correct. However, in response I would raise two points. First, that religious self righteousness allows little space to consider the validity of attitudes or practices which conflict with the view of the religious believer. And, that in the minds of some individuals and groups in Indonesia, this provides the justification needed to participate in vigilante activities such as 'anti-vice' raids, and these have been shown to be a pre-cursor to more serious violent actions, including terrorist attacks. ${ }^{19}$ For some, not all, religious people, the sense of unassailable correctness which stems from religious piety, is a slippery slope into bigotry and violence.

Second, on a far more fundamental level, religions are a means of dividing people. Religions are a very efficient means of allowing people to say, on a very deep level, 'I am this, and you are that' or 'You are different from me-you are the other'. Even the most tolerant religious people must acknowledge that, on a very fundamental ideological level, their religion defines them as something different to people of other religions (or those of no religion) and, conversely, that they share a special bond of identity with people of the same religion. This inherent divisiveness is perhaps religion's greatest obstacle to facilitating peace within humanity.

\footnotetext{
$16 \mathrm{Al}$ Makin, 'Plurality Denied: the defeat of pluralism advocates in Indonesia during the reformation era' (2012) (5 November 2012) Conference on Negotiating Diversity in Indonesia, School of Social Sciences Management University, Singapore November 5-6, 2012

${ }^{17}$ Ibid., p. 4.

18 Ibid., p. 3.

${ }^{19}$ ICG, 'Indonesia: From Vigilantism to Terrorism in Cirebon' (International Crisis Group, 26 January 2012 2012)
} 
It may also be stated that, of the almost-daily acts of terrorist violence which occur throughout the world, all of them, by definition, are committed by individuals who believe in the truthfulness or correctness of their religious or ideological beliefs. Defining terrorism is an enormously complex area of academic discourse. ${ }^{20}$ However, most definitions of terrorism include a "political, religious or ideological" component. Therefore, by definition, anyone who commits a terrorist act, is willing to kill or cause serious injury to others, because of their unshakeable conviction in an ideological cause of one sort or another. In that sense, absolute belief, or fanaticism, about any ideology, religious or secular, is dangerous. It is precisely this notion of unshakeable conviction which this paper seeks to shake.

In 1933, philosopher Bertrand Russell wrote an essay titled "The Triumph of Stupidity" that analysed the rise of the Nazi movement in Germany. He wrote:

The fundamental cause of the trouble is that in the modern world the stupid are cocksure while the intelligent are full of doubt. ${ }^{21}$

The quote was later paraphrased to: "the whole problem with the world is that fools and fanatics are always so sure of themselves and wiser people so full of doubt." 22 Along a similar line, the 17 th century philosopher Voltaire, stated "those who can make you believe absurdities can make you commit attrocities". ${ }^{23}$ Statements such as these are particularly relevant in the post- $9 / 11$ context of terrorism, particularly acts of suicide terrorism. Motivations of suicide bombers may be diverse, but there is no question that many, if not most, of the individual actors in what David Rapoport called "the current wave of

\footnotetext{
${ }^{20}$ See for example: Alex Schmid, 'Terrorism - the Definitional Problem' (2004) 36(2/3) Case Western Reserve Journal of International Law 375; Joshua Sinai, 'How to Define Terrorism. ' (2010) 2(4) (November 2010) Perspectives on Terrorism

21 Bertrand Russell, 'The Triumph of Stupidity' in Bertrand Russell (ed), Mortals and Others (Taylor \& Francis, 1933) 203 Russell also noted that lack of doubt of ideological fanatics may lead to dangerous consequences stating: "fanaticism is the gravest danger there is; I might almost say that I was fanatical against fanaticism" (emphasis added). Bob Lewis, 'A Word a Day IS Survival Guide ' (2001) 23(4) InfoWorld

${ }^{22}$ Lewis, above $\mathrm{n}$

${ }^{23}$ Voltaire, Questions sur les Miracles a M. Claparede.
} 
religious terrorism"24-as compared with the preceding waves of Anarchist, Anti-colonialist and New Left terrorism-are motivated by their strong religious beliefs.

Renaissance philosopher Rene Descartes, in his 1637 Discourse on the Method, 25 began his philosophical enquiry by observing that our intellect and our senses can lead us into error, and therefore doubted the existence of everything, before finally concluding that we cannot doubt of our own existence while we doubt. He concluded "I think, therefore I am". Descartes' exposition of sceptical doubt, signalled the birth of scientific method as a means of attaining knowledge; as distinct from beliefs which are received through other means such as tradition, authority or revelation.

In discussing tradition, authority and revelation as reasons for believing, Richard Dawkins wrote:

Tradition means beliefs handed down from grandparent to parent to child, and so on. Or from books handed down through the centuries. Traditional beliefs often start from almost nothing; perhaps somebody just makes them up originally, like the stories about Thor and Zeus. But after they've been handed down over some centuries, the mere fact that they are old makes them seem special. People believe things simply because people have believed the same thing over centuries. That's tradition.

The trouble with tradition is that, no matter how long ago a story was made up, it is still exactly as true or untrue as the original story was. If you make up a story that isn't true, handing it down over any number of centuries doesn't make it any truer! ${ }^{26}$

Dawkins similarly dismisses 'authority' and 'religious revelation' as unreliable sources of 'knowledge'.

When religious people just have a feeling inside themselves that something is true, they call their feeling 'revelation'. It isn't only

\footnotetext{
${ }^{24}$ David Rapoport, 'The Four Waves of Rebel Terror and September 11 ' (2002) 8 (1 Spring/Summer 2002) (2002) Anthropoetics - the Journal of Generative Anthropology

25 Veitch, John (1850). Discourse on the Method of Rightly Conducting the Reason, and Seeking Truth in the Sciences, by Descartes. Edinburgh: Sutherland and Knox. p. 74.

${ }^{26}$ For a discussion of "tradition, authority and revelation" as sources of unreliable beliefs see: Richard Dawkins, A Devil's Chaplain: Reflections on Hope, Lies, Science, and Love (Mariner Books, 2003) Chapter 7.1 Good and Bad Reasons for Believing pp 242-249.
} 
popes who claim to have revelations. Lots of religious people do. It is one of their main reasons for believing the things that they do believe. But is it a good reason? ... An inside 'feeling' on its own is not a good reason for believing ... You need evidence. ${ }^{27}$

\section{Indonesia and Freedom of Religion}

Indonesia has achieved great advances in freedom of expression and the media in the almost two decades since the fall of President Soeharto, and the subsequent era of reformasi. Public criticism of governmental processes and policy which would have been unthinkable under the Soeharto regime is now commonplace. ${ }^{28}$ However, despite this loosening of restrictions on public and media commentary, there are two main areas which remain taboo in Indonesian public discourse: atheism and communism-both of which are ideologically linked, and feared, in the minds of many Indonesians, ${ }^{29}$ even though left-flavored publication aspecially in campus circle started to flourish.

In a country where freedom of political expression, and freedom of religion, are both enshrined in the Constitution, it may be asked what historical and socio-political factors led to the widespread rejection and fear of alternative secular ideologies such as communism and atheism. The answer lies in Indonesia's unique history; Soekarno's formulation of the national philosophy of Pancasila, the Constitution and its subsequent amendments, a law on blasphemy from the mid1960s, and US-sponsored anti-communist purges which also occurred in the mid-1960s and led to the rise of Soeharto's 'New Order' government.

\footnotetext{
27 Ibid., p. 245.

${ }^{28}$ Kikue Hamayotsu, 'The Limits of Civil Society in Democratic Indonesia: Media Freedom and Religious Intolerance' (2013) 43(4) Journal of Contemporary Asia 658 The article notes that the rise of media freedom has also led to greater dissemination of intolerant views of conservative religious leaders.

${ }^{29}$ Ken Setiawan, 'The fear of communism still haunts Indonesia' (2016) Indonesia at Melbourne <http://indonesiaatmelbourne.unimelb.edu.au/belok-kiri-fest-fear-of-communism-still-haunts-indonesia/>; Randy Fabi and Kanupriya Kapoor, 'Indonesia's 'red scare' stokes unease over military's growing influence' (2016) Reuters
} 


\section{The Pancasila}

Despite frequent inaccurate media reports, Indonesia is not the world's largest Muslim country ${ }^{30}$-because Indonesia is not a Muslim country. It has the largest population of Muslim inhabitants, however, the philosophical foundation of the nation is not Islam, it is the Pancasila. The Pancasila is not of 'divine' origin. It was very clearly formulated by Indonesia's founding president Soekarno prior to the end of World War II, in June 1945. ${ }^{31}$ Indonesia declared Independence on 17 August 1945.

The Pancasila is taught to all Indonesian children in elementary school. ${ }^{32}$ It is learnt by rote and takes on the qualities of a mantra. It derives its name by joining two Sanskrit words: panca meaning five and sila meaning principle. The first sila, as any Indonesian can tell you, is Ketuhanan Yang Maha Esa - Belief in the one and only God. For completeness, the other five principles are listed here, but this discussion will be concerned primarily with the first principle. ${ }^{33}$

Soekarno dedicated an entire speech to how he formulated the philosophische grondslag or weltanschaunng of the embryonic Republic of Indonesia. The word weltanschanung appears over twenty times in the speech, as Soekarno describes the philosophical foundations of other countries, such as the National-Socialist doctrine of Hitler's Nazi Germany in 1933; Lenin's use of Marxism as the national ideology of Soviet Russia in 1917; and how Ibn Saud established the nation of Arabia on the weltanschaunng of a religion, Islam. He also referred to the

\footnotetext{
30 See for example: Ishan Tharoor, 'The world's largest Muslim country bans support for the Islamic State' (2014) The Washington Post < http://www.washingtonpost.com/blogs/worldviews/wp/2014/08/07/the-worlds-largest-muslim-country-banssupport-for-the-islamic-state/>

31 Tino Saroengallo and Tyo Pakusadewo, Pantja-Sila Cita-Cita \& Realita A Historical Documentary Film (2016)

32 In theoretical terms taken from the field of intercultural communications, cultural norms learned at an early age, known as 'basic assumptions', are among the deepest and most influential shapers of how individuals perceive the world around them, and in most cases individuals themselves are "unaware of their influence". Carlos Nunez, Raya Nunez Mahdi and Laura Popma, Intercultural Sensitivity: from denial to intercultural competence (Third Edition ed, 2014), 15.

33 (1) Belief in the one and only God, (2) Just and civilised humanity, (3) The unity of Indonesia, (4) Democracy guided by the inner wisdom in the unanimity arising out of deliberations amongst representatives, (5) Social justice for all of the people of Indonesia.
} 
Chinese San Min Chu I or Three Principles of Sun Yat Sen, and the Tennoo Koodoo Seishin of Imperial Japan, as the founding philosophies of those nations. Soekarno acknowledged that Sun Yat Sen's ideology of nationalism had had a particular impact on him.

For Soekarno, the question of statehood was primarily concerned with seeking unifying elements. One unifying element upon which Indonesia could be established was the land and sea which clearly gave it its geological boundaries and united person with land. "Even a little child, if shown a map of the world, can show that the Indonesian archipelago itself is a single entity. ${ }^{34}$ The Indonesian nation, according to Soekarno was not just one part, such as the Minangkabau, or Yogyakarta, "but all islands directed by God to be a single entity between two continents and two oceans, that is our homeland." 35 The reasoning is therefore based on the geographical positioning of the islands of Indonesia from "Sumatra to Irian" as the uniting factor and Soekarno placed an emphasis on the fact that this "nationhood" had two historical precedents; that is, the Sriwijaya and Majapahit kingdoms which Soekarno considered to be nationale staat.

Wishing to avoid national chauvinism Soekarno stated "we must advance toward world unity, a world of brotherhood. ${ }^{36}$ We do not only have to establish an independent state of Indonesia, but we must also move toward a family of nations. This, in fact, is my second principle"-the principle of 'internationalism' or 'humanity'. Soekarno's

\footnotetext{
34 Ibid., p. 95.

35 Ibid., p. 98.

36 The most radical idea contained in Soekarno's Pancasila speech, is one which was briefly raised and immediately rejected. It is an idea that was well before its time, but one which may, in time, come to be recognised as the only legitimate option for humanity in order to overcome conflict between groups and states. Soekarno stated "I do confess, when I was 16 years old, sitting in the H.B.S. school in Surabaya, I was influenced by a socialist named A. Baars, who taught me. He said: do not think in terms of nationality, but think of a global humanity, do not have the slightest thought of nationality. That happened in 1917. But in 1918, thank God, there was another who set me straight: Dr Sun Yat Sen, in his work San Min Chu I or The Three People's Principles...from that moment, in my heart was planted a sense of nationhood, the effect of The Three People's Principles." Saroengallo and Pakusadewo, above n , 101. The idea of abolishing all nations, while utterly radical, offers an opportunity to remove barriers between human groups and acknowledge only the common bond of humanity and a single global identity, that is, the condition of being a human inhabitant of Earth.
} 
third principle was 'consensus', 'representation' and 'deliberation', achieved through a representative body which would deliberate and achieve consensus. Soekarno saw this as the "best opportunity and place to nurture religion". ${ }^{37}$ Hence, Islam as a founding principle of the state was expressly excluded, while recognising that if, through democratic representation, Islam was the will of the people then it would be achieved through a representative assembly. "Supposing the one hundred members of the People's Representative Assembly work, work as had as possible, so that $60,70,80,90$ delegates who sit in the assembly are Muslims, so that the laws issuing from the House of Representatives are Islamic laws, too." 38

Soekarno's fourth sila was prosperity, which was a kind of compromise between Chinese Socialism and American Capitalism deliberately eschewing Western capitalism he said "Gentlemen, I propose that if we seek democracy, it should not be a western democracy but a consensus that affirms life...that is capable of bringing social prosperity."

In formulating his fifth and final sila Soekarno stated:

The fifth principle should be: build an independent Indonesia based on the submission to God Almighty. The Principle of Divinity. Not only an Indonesian nation that fears God, but each person should believe in God in his own way ... All people should believe according to their culture, without religious egoism ... Let us preach, practice our religion, whether Islam or Christianity, in a civilised manner. What is a civilised manner? It is respect: respect for one another. ${ }^{39}$

In Soekarno's original iteration of the Pancasila therefore, a belief in God was not the first principle of the state, or even the second, third or fourth. "Indonesian nationality", the condition of being a member of the peoples inhabiting the islands of the archipelago, was the first principle. It was only with the later intervention of Islamic factions in the independence committee that Belief in God was moved from its position as the fifth sila, to the first position. ${ }^{40}$

\footnotetext{
${ }^{37}$ Ibid., p. 103.

38 Ibid.

${ }^{39}$ Ibid., p. 110.

40 Along with moving Soekarno's fifth sila 'Belief in God' from fifth position to first position, the committee also altered the wording of the sila to make it compulsory for
} 
It would be wrong to conclude that because belief in God was last on Soekarno's list of five principles, that it was not important to him; it clearly was. However, it was also clearly not the predominant factor of Indonesian-ness. Soekarno discussed the relevance of the number five as being significant; five fingers, five senses, five pillars of Islam. However, he suggested that the five principles, could, if necessary, be condensed to three - which he listed as Socio-nationalism, Sociodemocracy, and Divinity - comprising, not a Pancasila, but a Trisila.

Taking the notion of condensing even further, Soekarno postulated that if he were to condense all five silas to three, and three to one, it would be the principle of gotong-royong. Effort, contribution, work, pulling together, all religions, indigenous and other ancestries an Ekasila, or Single Principle. Soekarno left it to the committee to determine which of the three: Panca Sila, Tri Sila or Eka Sila, would be chosen as the founding principle of the independent Indonesia. He said:

Or perhaps there are those of you who do not like the number five? I can condense these principles from five to three... But perhaps not all of you gentlemen are happy with this Tri Sila, and ask for one, just one basic principle? Very well... If I condense the five to three, and the three becomes one, I arrive at a genuine Indonesian word: gotong royong... This, gentlemen is what I propose to you. Panca Sila became Tri Sila, Tri Sila became Eka Sila. But it is up to you gentlemen which to choose: Tri Sila, Eka Sila or Panca Sila? I have already explained the content. ${ }^{41}$

It is therefore, by quirk of history that Indonesia has a Pancasila with its first tenet as a belief in God. If the Independence Committee had chosen Soekarno's Ekasila as the weltanschaumng of the new republic there would have been no mention of God whatsoever in Indonesia's founding philosophy, and this could have drastically altered the

Muslim Indonesians to adhere to Shariah law. In the second version of the pancasila, the first tenet therefore became: "Belief in God with the obligation for Muslims to adhere to Islamic law" - which became known as the 'Jakarta Charter'. The 'seven little words' of the Jakarta Charter were "dropped at President Soekarno's insistence as the Constitution was being finalised in 1945. This was in part because of fears that Christians in Eastern Indonesia would abandon the new Republic, and in part because of secular nationalist objection." Tim Lindsey (ed), Indonesia: Law and Society (Federation Press, 2nd Edition ed, 2008) 41.

${ }^{41}$ Saroengallo above n p. 18, pp. 112-113. 
nation's history. The Pancasila underwent several revisions in subsequent years with slight alterations to the wording, but belief in an 'Almighty God' or 'Deity' remained at the top of the list of five tenets - and generations of Indonesian children were indoctrinated in Indonesian schools to accept, without question, the existence of God as a fundamental belief, and a quality of their Indonesian-ness. A belief in God is therefore part of what it means to be Indonesian.

One aspect of Soekarno's Pancasila speech which is also relevant to this discussion, is that he was strongly opposed to bigotry or 'chauvinism'. He repeatedly stated that "Indonesia should be a nation where each person may worship their own God in their own way" and stressed the need to "respect the beliefs of others". He was likewise opposed to national chauvinism, and strongly in favour of a unified brotherhood of nations, of which Indonesia would form a part.

While Soekarno considered himself a Muslim, he admitted his faults stating "a thousand apologies if my practice of Islam is far from perfect - but if you opened my chest, and saw I had a heart, gentlemen, you would find none other than a heart of Islam." Clearly, Soekarno considered himself religious, and a Muslim, but his approach was not bigoted, or superior, or self-righteous; it was conciliatory, inclusive, respectful and tolerant - "we must advance toward world unity, a world of brotherhood". 42 What Soekarno did not explicitly address, was an Indonesia where citizens would have the freedom to have no religious faith. His vision of Indonesia was one of "humanity" "consensus" "peace and safety" and "a belief in an all-encompassing and perfect God". ${ }^{43}$ While his approach was conciliatory and inclusive, it apparently left no room for atheism or agnosticism, and effectively created a state-mandated belief in God which was compulsory for all citizens of the new republic. This compulsory belief in God, albeit with "freedom of religion", was reinforced in the national Constitution.

\section{The Indonesian Constitution}

The Preamble to the Indonesian Constitution states "the independence of Indonesia shall be formulated into a Constitution of the Republic of Indonesia which shall be built into a sovereign state

\footnotetext{
42 Ibid., p. 102.

43 Ibid.
} 
based on a belief in the One and Only God". ${ }^{44}$ It goes on to restate, in full, the remaining tenets of the Pancasila, thus enshrining them, in principle, into constitutional law.

Article 28E(1) states "Every person shall be free to choose and to practice the religion of his/her choice...(2) Every person shall have the right to the freedom to believe his/her faith (kepercayaan) and to express his/her views and thoughts, in accordance with his/her conscience. (3) Every person shall have the right to the freedom to associate, to assemble and to express opinions.

Article 28I(1) states "The rights to life, freedom from torture, freedom of thought and conscience, freedom of religion, freedom from enslavement, recognition as a person before the law, and the right not to be tried under a law with retrospective effect are all buman rights that cannot be limited under any circumstances. ${ }^{45}$ (2) Every person shall have the right to be free from discriminative treatment based upon any grounds whatsoever and shall have the right to protection from such discriminative treatment.

Chapter XI Religion, states at article 29 (1) The State shall be based upon the belief in the One and Only God. (2) The state guarantees all persons the freedom of worship, each according to his/her own religion or belief.

The Indonesian Constitution therefore, in articles 28E, 28I and 29 contains no less than four separate guarantees of freedom of religion, faith or belief, as well as protections from any kind of discriminative treatment, and to express opinions or beliefs.

However, the Constitution also states in the Preamble and article 29 that the Indonesian state is based on a belief in the One and Only God. Therein lies a paradox. Freedom of religion, faith, belief or conscience, must include the freedom to have no religion, faith, belief or conscience. If a person cannot be compelled to believe or convert to a particular one of the belief systems, how can a person be compelled to believe in any of them? It is tantamount to saying, while we guarantee that you cannot be forced to believe in a, b, c or d, you can be forced to believe in one of them, and you must choose one. This is a logical absurdity which is not adequately addressed by Indonesia's

\footnotetext{
${ }^{44}$ Indonesian Constitution 1945 Preamble.

${ }^{45}$ Emphasis added.
} 
Constitution or legislation. ${ }^{46}$ In fact, Indonesia's Law No. 1 of 1965 compounds the absurdity by limiting the number of state-recognised religions to six: Islam, Catholicism, Protestantism, Hinduism, Buddhism and Confucianism.

Art 28J(2) of the Constitution also states that the rights and freedoms are subject to the "restrictions established by law for the sole purposes of guaranteeing the recognition and respect of the rights and freedoms of others and to satisfying just demands based upon considerations of morality, religious values, security and public order in a democratic society". As stated below, Indonesia's Constitutional Court placed great signficance on this section in upholding the Blasphemy Law of 1965 which was challenged for being unconstitutional insofar as it limits the freedom of religion principles outlined above.

\section{Law No. 1 of 1965 on Blasphemy}

Law No. 1 of 1965 on the Prevention of the Abuse of Religion and/or Blasphemy (hereinafter 'the Blasphemy Law') is the most often cited and most visible state apparatus for limiting individual religious freedom, and the religious plurality of Indonesian society. It has been the subject of an unsuccessful Constitutional Court challenge. ${ }^{47}$ The Blasphemy Law, which contains only four succinct articles, prohibits anyone from "publicly deliberately speaking about, recommending, or lending support to interpretations of a religion which deviate from the central teachings of that religion" (Article1). Where an individual commits such an offence, they are to be given a warning by joint letter issued by the Minister of Religion, the Attorney General and the Minister of Internal Affairs (article 2(1)). Where an organisation or

\footnotetext{
${ }^{46}$ Interestingly, art 9(1) of the Indonesian Constitution allows Presidents and Vice Presidents the option of swearing a religious oath, or a non-religious affirmation which contains no reference to God. This appears to allow Presidents and VPs a liberty which is not extended to other citizens; for example when giving testimony in legal proceedings individuals are required to be sworn in according to their religion. In the Blasphemy Case, one witness who asked to be sworn in using, not the words of any of the six officially sanctioned religions, but the Pancasila, was told by the Chief Judge of the Constitional Court that "there is no such thing as swearing by the Pancasila." Indonesian Legal Resource Center (ed), Bukan Jalan Tengab: Eksaminasi Publik Putusan Mabkamah Konstitusi Peribal Pengujian Undang-Undang Nomor 1 PNPS Tabun 1965 Tentang Penyalahgunaan dan/atau Penodaan Agama (2010), p. 14.

${ }^{47}$ Ibid.
} 
'aliran kepercayaan' (sect) commits an offence, the President may disband and ban the group (article 2(2)). If, after the warning, the individual or group continues to offend against article 1, the individuals, followers, members or leaders of the organisation may be imprisoned for up to five years (article 3). Article 4 of the law inserts an article into the Criminal Code, article 156a, to give effect to the provisions set out above. In full, article 4 states:

A punishment of up to five years imprisonment shall be applied to any person who, in public, expresses an opinion or an action: (a) Which is characterised by enmity, abuse or blasphemy against a particular religion which is followed in Indonesia; (b) Which is intended so that others will not follow any religion, which is the basis of the principle of A Belief in the One and Almighty God. ${ }^{48}$

By virtue of article 156a therefore, anyone who publicly espouses "deviant" interpretations of religion, or atheism, commits a criminal offence, punishable by up to five years imprisonment.

President Soekarno signed the Blasphemy Law into existence as a Presidential Decree on 27 January 1965. It was only later, in 1969, that the Presidential Decree was elevated to the status of national legislation (undang-undang) through the enactment of Law No. 5 of 1969 on the Enactment of Various Presidential Decrees as Legislation. The Blasphemy Law was among a tranche of 72 presidential decrees, made between the years 1959 and 1969, which were converted into legislation by Law No. 5 of 1969.

The body of the Blasphemy Law itself contains no reference to the six religions which are famously 'recognised' by the Indonesian state. These passages are contained in the elucidation; the explanatory notes which come after the main articles of the law.

Before proceeding to examine the contents of the elucidation it should be noted that the legal status of text contained in the elucidation may be questionable. ${ }^{49}$ Article 176 of Appendix I of Law No. 12 of 2011 on the Formulation of Legislation, states:

176. The elucidation is the official interpretation, by the legislators, of certain norms in the body of the law. Therefore the

\footnotetext{
48 Author's translation.

49 Adi Condro Bawono, 'Fungsi Penjelasan dan Lampiran Peraturan Perundangundangan' (2012) bukumonline < http://www.hukumonline.com/klinik/detail/cl6386/fungsi-penjelasan-dan-lampiran-peraturan-perundang-undangan $>$
} 
elucidation only contains a commentary/analysis/clarification ('uraian') of words, phrases and sentences.

177. The elucidation may not be used as a legal basis for the formation of further regulations, and may not contain normative formulations.

178. The elucidation may not use formulations which would import changes of meaning to the provisions of the legislation. ${ }^{50}$

Appendix I of Law No. 12 of 2011 further states, at article 186, that "the elucidation may not conflict with, broaden, narrow, or add to the normative definition of provisions in the body of the law". Essentially therefore, the elucidation should only provide an explanation of the text contained in the law and should not contain new substantive material which is not contained in the law itself. It is highly arguable that the bounds of what an elucidation is supposed to do have been stretched beyond breaking point in the case of the Blasphemy Law and its entire legal authority for limiting the practice of religion in Indonesia to six major recognised religions is highly questionable in term of legality. This question ought to be raised in the event of another constitutional challenge to the law.

In the case of the Blasphemy Law, the elucidation contains the real substance and raison d'etre of the law itself. Note 1 restates the five principles of the Pancasila, followed by:

As the first principle, a belief in the One and Almighty God does not only provide a moral basis for the state and the government, it also ensures national unity based on religion.

Recognition of the first sila (Belief in the One and Almighty God) cannot be separated from religion, because it is one of the fundamental pillars of human existence and for the people of Indonesia it is also a principle of the state and an integral element in nation-building.

The second note explains the reason that the law was enacted by President Soekarno, that is, that there was a burgeoning number ${ }^{51}$ of

\footnotetext{
${ }^{50}$ Author's translation.

51 A report of Indonesia's Department of Religion in 1953 stated that there were over 360 religious sects in Java. The divergence of religious groups may have been a determinative factor in the failure of Islamic parties to achieve a majority at the 1955
} 
sects and faiths, many of which diverged from the teachings of the large recognised religions. It states:

In recent times, all over Indonesia, a large number of sects, organizations and beliefs have emerged in the community, which conflict with religious teachings and laws.

Among those teachings and activities followers of those sects/beliefs which contravene law, and threaten national unity and blaspheme against religion... the growth of such organisations is extremely dangerous for existing religions.

The article-by-article elucidation, with regard to article 1 of the Blasphemy Law states:

Religions which are followed by Indonesian citizens are Islam, Christianity, Catholicism, Hinduism, Buddhism and Khong $\mathrm{Hu} \mathrm{Cu}$ (Confucianism).

This is proven by the historical development of religions in Indonesia.

Because these six religions are followed by almost all of Indonesia's citizens...they receive the assistance and protections [as set out in article 1].

This does not mean that other religions, such as Judaism, Zoroastrianism, Shintoism, Taoism, are forbiddden in Indonesia. They receive the full protection of article 29(2) [of the Constitution] and their existence is allowed ("dibiarkan adanya"), as long as they do not contravene the provisions set out in this law or other laws.

With regard to other sects/beliefs, the government should take steps to channel these into a healthy belief which is in line with Belief in the One and Almighty God. ${ }^{52}$

By mandating criminal sanctions for any person who publicly professes beliefs "which deviate from the fundamental teachings of a particular religion" it then becomes encumbent on the state to determine and adjudicate what are the normative teachings of each of those recognised religions - which the Indonesian authority has done

election. The Blasphemy Law was therefore an attempt by Soekarno to balance the competing forces of nationalism, religion and communism. Center, above n, p. 1.

52 Author's translation. 
through the Ministry of Religion. While other established religions such as Judaism were expressly "allowed" to exist, other indigenous beliefs and sects were urged to be "guided" into line with the national philosophy of belief in one God. This effectively meant that they would be placed under the umbrella heading of one of the recognised religions, or, criminalised.

\section{Constitutional Court Challenge to the Blasphemy Law}

In 2010, a number of community organisations banded together and mounted a challenge to the Blasphemy Law in Indonesia's Constitutional Court. ${ }^{53}$ The case received a great deal of public attention and heard evidence from dozens of expert witnesses. Hard line religious groups such as FPI and GARIS attended the trial, demonstrated and even intimidated witnesses who were in favour of repealing the Blasphemy Law. Witnesses in favour of repealing the law were equated with being atheists, communists and satan worshippers ${ }^{54}$ through intimidating chanting and threats. Several witnesses were threatened with death, and shouts that to spill their blood would be "halal" (permissable under Islamic law). ${ }^{55}$

In its final decision, the Constitutional Court, in a majority 8-1 decision rejected the application to repeal the Blasphemy Law as unconstitutional. Its decision was based, on two main arguments, first, that the Blasphemy Law must be viewed in an Indonesian context. It stated:

Indonesia's recognition of international law, including human rights, must still be based on the philosophy and Constitution of the Unitary Republic of Indonesia. As such, Indonesia's administrative law does not have to equate with rechstaat, the rule of law, individualism or communalism..$^{56}$

The wording seems quite clearly to argue that, while Indonesia is a signatory to international declarations of human, civil and political rights, that the provisions of those international laws must be viewed through the prism of Indonesian-ness, and discarded to the extent of any conflict.

\footnotetext{
${ }^{53}$ Ibid.

54 Ibid., p. 27.

55 Ibid., pp. 29-35.

56 Ibid., p. 39.
} 
Second, the judgement was based on the argument that freedom of religion is not an absolute freedom, and that it must be limited in order to maintain harmony and order. The Constitutional basis of this argument derives from art 28J(2) of the Constitution which allows the restrictions on freedoms for the purposes of "public order". This argument basically says that allowing freedom of religion, or the freedom to reinterpret religious tenets, can be the source of disagreement, offence, hatred, horizontal violence (between groups), vertical violence (between groups and the state) and, taken to its extreme, anarchy. The case of the Ahmadiyah is a classic example of a group which has reinterpreted religious texts, caused offence to other religious groups, which led to violence. This line of reasoning however does not recognise that allowing the "fundamental teachings" of religions to be set by a governmental body, reinforces the selfrighteousness and intolerant thinking of those who follow the mainstream 'state-endorsed' belief system. When the MUI issued a fatwa on the deviant Ahmadiyah sect, it was taken as a 'green light' on the part of hard-line groups to persecute the minority sect which had been officially 'outed'. ${ }^{57}$

Finally, as Tim Lndsey and Helen Pausacker observe with regard to the Blasphemy Law, it can be noted that the use of the law in the Post-Soeharto era is increasing:

The post-Soeharto application of the Criminal Code dealing with religion shows two clear features: first, increased use overall, and, second, a heavy focus on the repression of relatively minor unorthodox sects. Typically these are characterised as 'deviant' and as implicit threats to state-sanctioned orthodox religious belief, to the extent that they seem also to be viewed as subversive and a threat to the state itself, although this seems an absurd exaggeration of the 'danger' posed by the tiny, eccentric groups usually targeted. ${ }^{58}$

The question of "orthodoxy" is usually determined by the conservative views of the MUI which means that "this organisation

\footnotetext{
57 Bernhard Platzdasch, 'Religious Freedom in Indonesia: The Case of the Ahmadiyah' (Institute of South East Asian Studies, 2011) < http://web1.iseas.edu.sg/wpcontent/uploads/2010/11/Religious-Freedom-in-Indonesia1.pdf $>$

58 Tim Lindsey and Helen Pausacker, Religion, Law and Intolerance in Indonesia (Routledge, 2016).
} 
continues to accrue significant de facto power as a sort of informal religious police force." 59 Similar tactics are used to curtail larger deviant groups such as Ahmadiyah. "State action follows, or is accompanied by, condemnation by MUI or another conservative Muslim organisation and then violence - led by militant Islamist groups - that the state usually declines to punish. There is little hope of change in these patterns of state repression if the Criminal Code is amended or the current Religious Harmony draft bill passed, as the amendments currently proposed to both of these statutes would only make the position of minority groups even weaker. ${ }^{60}$

However, there may be some hope for change. One out of the nine judges on Indonesia's Constitutional Court bench, in a dissenting judgement, argued for the repeal of the Blasphemy Law, saying that it created inconsistent treatment between recognised religions, and other religions. Further, the judge stated that the government had entered into the murky waters of regulating matters of spirituality which were best left to the individual. And, that through various state mechanisms such as the issuing of identity cards, marriage and death certificates, the recognised religions were in a superior position to people who professed other beliefs, and that the criminal sanctions of the Blasphemy law had been applied arbitrarily. Due to the many inconsistencies and unfairness which the Blasphemy Law creates, the judge, Maria Farida, therefore agreed that it should be repealed. However, she was a minority of one out of nine.

\section{Anti-Communist Purge of 1965}

The timing of the Blasphemy Law of 1965 is signficant, and must be viewed in the historical context of a global 'cold war', and responses to the expansion of communism. Following Indonesia's declaration of Independence in 1945, recalling that in formulating the Pancasila Soekarno placed particular emphasis on the teachings of Sun Yat Sen, Soekarno's relations with ethnic Chinese Indonesians, and with China itself, were good. While this is a complex period of history with many conflicting accounts, what is clear is that Soekarno's connections with Communist China, and the growing influence and strength of the Indonesian Communist Party (Partai Komunis Indonesia, the 'PKI')

\footnotetext{
59 Ibid.

${ }^{60}$ Ibid.
} 
culminated in a set of events on 30 September 1965 which altered the course of Indonesia's history - and led to Soeharto's gradual take-over of power from President Soekarno. A nation-wide massacre of suspected communists took place in the years 1965/6 which is unprecedented in Indonesian history. Estimates vary, but anywhere between 500,000 to $3,000,000$ people were murdered in a bloodbath which spilled over into many of the islands of the archipelago. The massacre was also accompanied with a wide-spread campaign to rid Indonesia of all Chinese influence, including by banning Chinese characters, newspapers, names, associations and so on. A former Chinese-Singaporean diplomat gave a succinct account of this transformation in Indonesian history:

The Suharto regime closed down all Chinese schools, banned all Chinese newspapers and did not even allow Chinese characters to be displayed in Indonesia... I remember when I first visited Jakarta and Bandung in 1955 during the Afro-Asian Conference that there were still Chinese signboards everywhere. Chinese newspapers fought out their Chinese ideological war on Indonesian soil and Chinese schools could be seen in every village. When I visited Indonesia again in 1960 with Prime Minister Lee Kuan Yew to see President Sukarno, there were still Chinese newspapers and Chinese schools and Chinese signboards. But when I went to Indonesia to present credentials to President Suharto, there were no more Chinese signboards nor any Chinese associations or schools or newspapers. Not only was the Chinese language considered "harmful", but even Chinese religion and customs were regarded as undesirable... In 1967 a Presidential instruction stated that Chinese religion, beliefs and customs...might generate unnatural influence on the psychology, mentality and morality of Indonesian citizens and impede prosperity... Since the Indonesian state ideology, the Pancasila, included "Belief in God" as the first principle, every person in Indonesia was expected to have a religion of some kind. ${ }^{61}$

In the context of resisting the global expansion of communism, the involvement of the US in Indonesia's affairs cannot be ignored, and arguably played a crucial role in the annihilation of communism, and the acute stigmatisation of atheism, in Indonesia. A report in the

${ }^{61}$ Khoon Choy Lee, A Fragile Nation: the Indonesian Crisis (World Scientific, 2010) 
Washington Post in 1990 outlined US involvement in "one of the century's worst massacres" stating:

U.S. officials 25 years ago supplied the names of thousands of members of the Indonesian Communist Party to the army in Jakarta, which at the time was hunting down the leftists and killing them in a crackdown branded as one of the century's worst massacres, former U.S. diplomats and CIA officials say.

For the first time, the officials are acknowledging that they systematically compiled comprehensive lists of communist operatives, from the top echelons down to village cadres in Indonesia, the world's fifth most populous nation. As many as 5,000 names were furnished over a period of months to the army there, and the Americans later checked off the names of those who had been killed or captured, according to the former U.S. officials.

The assassinations were part of a massive bloodletting that decimated the Partai Komunis Indonesia (PKI) in Indonesia, a Southeast Asian archipelago of more than 13,500 islands. The PKI was the third-largest Communist Party in the world at the time, with 3 million members, and through affiliated organizations -such as labor and youth groups -- it claimed the loyalties of 17 million others. ${ }^{62}$

The US, which was already in a protracted war against communism in Vietnam, saw Indonesia's growing support of communism, both in the president and the populace, as a serious threat. Indonesia's PKI, with 3 million members and the loyalty of 17 million more, represented a growing problem which needed to be dealt a decisive blow.

The US-endorsed, Suharto-led military crackdown on Indonesia's communist party, was so lethal, so ruthless and so complete, that the repercussions continued to be felt throughout the following decades, and to this day. In 2016, relatives of those killed in the 1965/6 massacres, clearly still stigmatised, traumatised and intimidated by their

\footnotetext{
${ }^{62}$ Kathy Kadane, 'US Officials lists aided Indonesian bloodbath in 60s' (1990) The Washington Post <https://www.washingtonpost.com/archive/politics/1990/05/21/us-officials-lists-aided-indonesian-bloodbath-in-60s/ff6d37c3-8eed-486f-908c-3eeafc$19 \mathrm{aab} 2 />$
} 
'connection to communism' sought, not to be able to reintroduce communism to Indonesia, but only some kind of reconciliation. ${ }^{63}$

Haryono, spokesman of Lembaga Perjuangan Rehabilitasi Korban Orde Baru, an NGO working for the rehabilitation of New Order regime victims, said many people had become victims in the 1965 killings, thus it was important for the government to extend an apology.

"We don't want to re-raise communism in Indonesia. We just ask the President to engage in reconciliation," said Haryono.

The National Commission on Human Rights (Komnas HAM) decided on July 23, 2012, that violence committed after the Sept. 30,1965 , incident amounted to gross human rights violations... According to Komnas HAM, the number of those killed in the 1965 anti-communist purge was somewhere between 500,000 and three million people. ${ }^{64}$

Indonesia's anti-communism, and therefore anti-atheism, remains so strong that in 2016, two Indonesian student activists wearing satirical T-shirts with the letters "PKI" - a play on words meaning "Indonesian Coffee Lover" - were detained by military authorities for "spreading communism through T-shirts". ${ }^{65}$

\section{Conclusion}

A unique Pancasila-based religious orthodoxy exists in Indonesia. It states that, while citizens have a kind of religious freedom - the freedom to choose from six major state-recognised religions - it also states that citizens essentially must choose one, and any kind of religious activity or belief which goes beyond that is deeply questionable, and quite possibly criminal. This religious orthodoxy appears to be growing and is reinforced through many of the mechanisms mentioned in this paper: the growing influence of Indonesia's quasi-governmental religious arbiter the MUI, the growth of Islamic-based regional regulations, the growth of prosecutions of 'deviant' sects under the Blasphemy Law, residual anti-communist/-

\footnotetext{
63 Anton Hermansyah, '1965 victims: We don't want communism, just reconciliation' (2016) The Jakarta Post <http://www.thejakartapost.com/news/2016/04/19/1965victims-we-dont-want-communism-just-reconciliation.html>

${ }^{64}$ Ibid.

${ }^{65}$ Fabi and Kapoor, above $n$
} 
atheist prejudices from the events of the 1960s, Constitutional Court decisions which reinforce limitations on religious freedom, and the continued emphasis on the first tenet of Pancasila, a belief in God. It is unlikely, therefore, that Singer's "unaccustomed mental switch" to "rethink" our own most fundamental beliefs, is going to happen in Indonesia on any large scale, any time soon.

When it was publicly revealed that one of Indonesia's leading state universities was running an information and support campaign for LGBT students, it caused a massive backlash from religious and governmental institutions. ${ }^{66}$ Any movement of that kind towards recognising the legitimacy of alternative ideological viewpoints such as atheism or agnosticism would likely be met with the same swift and forceful resistance from Indonesia's state and religious institutions. Still, a dissenting opinion by a judge of Constitutional Court on the Blasphemy Law proves there is still hope.

The Indonesian state may have mandated a belief in God, and it may be able to legislate and criminalise people's public expressions of faith, however, it cannot legislate thoughts. There are an unknown, but possibly growing, number of individuals and groups in Indonesia which espouse alternative ideologies and beliefs to those of the mainstream including, atheists, agnostics and LGBTs among others. They and other groups and NGOs which operate outside the mainstream exist and fight daily for equality of treatment for marginalised groups while treading a fine line between freedom of speech and prosecution. Further research is needed about the prevalence of these non-mainstream groups, and about how those in Indonesia's scientific community engage with, and reconcile, their religious beliefs and scientific practices.

Indonesia's national motto, Bhinneka Tunggal Ika, is commonly translated as "unity in diversity". It appears that, at present, the principle of "unity" trumps that of "diversity". Indonesia's advancement in, and global contribution to, science, pluralism and tolerance remains compromised while the prevailing and growing religious attitudes remain. Whether Indonesia is ready for a public debate about the "unaccustomed mental switch" which would allow a space in society for non-mainstream religious points of view including

${ }^{66}$ Liang and IA, above $\mathrm{n}$ 
indigenous belief systems as well as atheism ${ }^{67}$ and agnostism, remains doubtful.

By mandating a belief in God, limiting the choices of legitimate state-recognised religions, and reinforcing institutionalised bias, the Indonesian state is perpetuating attitudes of religious righteousness, bigotry and intolerance towards religious and ideological minorities. This position, which is purposely designed to maintain a national status quo in religious affairs, inadvertently hampers counter-narratives aimed at jihadist and radical Islamist ideologies-as well as any kind of innovative thought which challenges inherited belief structures. The role of Indonesia's secondary and tertiary education systems in producing graduates who are able to think critically, and innovate when necessary, will be key to the country's ability to compete effectively in an increasingly integrated global community.]

\section{References}

\section{Books and Articles}

Amin, Kamaruddin, 'Can Indonesian Islam be a Model for the Rest of the Muslim World?' (2016) The Jakarta Post <http://www.thejakartapost.com/news/2016/05/20/can-indonesian-islam-be-amodel-for-the-rest-of-the-muslim-world.html>

Bawono, Adi Condro, 'Fungsi Penjelasan dan Lampiran Peraturan Perundang-undangan' (2012) bukumonline <http://www.hukumonline.com/klinik/detail/cl6386/fungsi-penjelasan-danlampiran-peraturan-perundang-undangan $>$

Beech, Hannah, 'What Indonesia Can Teach the World About Counterterrorism' (2010) TIME <http://www.time.com/time/magazine/article/0,9171,1992246,00.html\#ixzz1THb0itB $\mathrm{v}>$

Center, Indonesian Legal Resource (ed), Bukan Jalan Tengab: Eksaminasi Publik Putusan Mabkamah Konstitusi Peribal Pengujian Undang-

\footnotetext{
${ }^{67}$ Importantly this needs to include a discussion which "detaches" atheism from communism, and recognises that the two are separate and different ideas. Many western scientists, including for example Richard Dawkins, are atheists, but not communists. This is not generally well understood in mainstream Indonesian thinking, where, partly because of the taboo surrounding discussions relating to events of 1965 , the two are often understood as being inseparable.
} 
Undang Nomor 1 PNPS Tabun 1965 Tentang Penyalabgunaan dan/ atau Penodaan Agama (2010)

Cochrane, Joe, 'Embrace of Atheism Put an Indonesian in Prison' (2014) New York Times <http://www.nytimes.com/2014/05/04/world/asia/indonesian-who-embraced-atheism-landed-inprison.html>

Crouch, Melissa, 'Implementing the Regulation on Places of Worship in Indonesia: New Problems, Local Politics and Court Action' (2010) 34 Asian Studies Review 403

Dawkins, Richard, A Devil's Chaplain: Reflections on Hope, Lies, Science, and Love (Mariner Books, 2003)

Fabi, Randy and Kanupriya Kapoor, 'Indonesia's 'red scare' stokes unease over military's growing influence' (2016) Reuters

Freelon, Deen et al, 'Town Halls of the Digital Age: Controversy and Ideology in Online Deliberation (and Beyond)' (2008) October 16-18, 2008(Paper ID: 238) Internet Research 9.0 IT University of Copenhagen

Hamayotsu, Kikue, 'The Limits of Civil Society in Democratic Indonesia: Media Freedom and Religious Intolerance' (2013) 43(4) Journal of Contemporary Asia 658

Hermansyah, Anton, '1965 victims: We don't want communism, just reconciliation' (2016) The Jakarta Post <http://www.thejakartapost.com/news/2016/04/19/1965-victims-we-dont-wantcommunism-just-reconciliation.html>

ICG, 'Indonesia: From Vigilantism to Terrorism in Cirebon' (International Crisis Group, 26 January 2012 2012)

Kadane, Kathy, 'US Officials lists aided Indonesian bloodbath in 60s' (1990) The Washington Post <https://www.washingtonpost.com/archive/politics/1990/05/21/us-officials-lists-aidedindonesian-bloodbath-in-60s/ff6d37c3-8eed-486f-908c3eeafc19aab2/>

Karmini, Niniek, 'No Shame for Religious Killings in Indonesian Town', The Jakarta Globe August 09, $20112011<\underline{\text { http://www.- }}$ thejakartaglobe.com/home/no-shame-for-religious-killings-inindonesian-town/458163> 
Lee, Khoon Choy, A Fragile Nation: the Indonesian Crisis (World Scientific, 2010)

Lewis, Bob, 'A Word a Day IS Survival Guide ' (2001) 23(4) InfoWorld

Liang, Jamison and IA, 'Morality and LGBT rights in Indonesia ' (2016) New Mandala <http://www.newmandala.org/moralityand-lgbt-rights-in-indonesia/ $>$

Lindsey, Tim (ed), Indonesia: Law and Society (Federation Press, 2nd Edition ed, 2008)

Lindsey, Tim and Helen Pausacker, Religion, Law and Intolerance in Indonesia (Routledge, 2016)

Makin, Al, 'Plurality Denied: the defeat of pluralism advocates in Indonesia during the reformation era' (2012) (5 November 2012) Conference on Negotiating Diversity in Indonesia, School of Social Sciences Management University, Singapore November 5-6, 2012

Nunez, Carlos, Raya Nunez Mahdi and Laura Popma, Intercultural Sensitivity: from denial to intercultural competence (Third Edition ed, 2014)

Platzdasch, Bernhard, 'Religious Freedom in Indonesia: The Case of the Ahmadiyah' (Institute of South East Asian Studies, 2011) <http://web1.iseas.edu.sg/wp-content/uploads/2010/11/Religious-Freedom-in-Indonesia1.pdf $>$

Rane, Halim, 'Narratives and Counter-narratives of Islamist Extremism' in Anne Aly et al (eds), Violent Extremism Online: New Persectives on Terrorism and the Internet (Routledge, 2016)

Rapoport, David, 'The Four Waves of Rebel Terror and September 11 ' (2002) 8(1 Spring/Summer 2002) (2002) Anthropoetics - the Journal of Generative Anthropology

Russell, Bertrand, 'The 'Triumph of Stupidity' in Bertrand Russell (ed), Mortals and Others (Taylor \& Francis, 1933) 203

Saroengallo, Tino and Tyo Pakusadewo, Pantja-Sila Cita-Cita \& Realita A Historical Documentary Film (2016)

Schmid, Alex, 'Terrorism - the Definitional Problem' (2004) 36(2/3) Case Western Reserve Journal of International Law 375

Sedgwick, Mark, 'Jihadist ideology, Western counter-ideology, and the ABC model' (2012) 5(3) Critical Studies on Terrorism 359 
Setiawan, Ken, 'The fear of communism still haunts Indonesia' (2016) Indonesia at Melboume <http://indonesiaatmelbourne.unimelb.edu.au/belok-kiri-fest-fear-of-communism-still-hauntsindonesia/>

Silverman, Jacob, 'That Propaganda Program Bill Clinton Praised Hillary for? It Was Considered a Failure.' (2016) Politico Magazine <http://www.politico.com/magazine/story/2016/07/bill-clinton-hillary-clinton-counter-messaging-radicalizationislamists-214112>

Sinai, Joshua, 'How to Define Terrorism. ' (2010) 2(4) (November 2010) Perspectives on Terrorism

Singer, Peter, 'All Animals Are Equal ' in Tom Regan and Peter Singer (eds), Animal Rights and Human Obligations (Prentice Hall, Second ed, 1989) 148

Tharoor, Ishan, 'The world's largest Muslim country bans support for the Islamic State' (2014) The Washington Post < http://www.washingtonpost.com/blogs/worldviews/wp/2014/08/07/theworlds-largest-muslim-country-bans-support-for-the-islamicstate $/>$

Undang-Undang No. 12 Tahun 2011 tentang Pembentukan Peraturan Perundang-Undangan

Xueling, Lin, 'Exclusive: We want to partner ASEAN countries that represent best of moderate Islam, says Obama' (2016) Channel News Asia <http://www.channelnewsasia.com/news/asiapacific/ exclusive-we-want-to/2533520.html $>$ 
Adam J. Fenton

212 JOURNAL OF INDONESIAN ISLAM

VOLUME 1O, NUMBER O2, DECEMBER 2016 